UDC 621.311 .16

\title{
電力系統解析及び制御のための統一的 感度係数決定法
}

早稻田大学 横 山 隆一

\section{1. まえがき}

雬力の質上経济性の磼保老目的とした平常時の周波

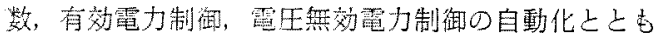
に，事故封の柔統操作や事故波及防止対策といった供 給信頛度の面からの軍用自動化が見直され，上り総合 的な制御体系の確立方必要となっている。

このような電力系続の㖶用方るいはこの前段階の運 用計画に古たり，各種のオフ・ライン，オン・ライン による信頼性チェックと対策計算が奏施さ机る。第 1 表は通常心電力系統運用に用いら机る制御用基礎デー 夕を气の使用目的化徒い分類したものである。(1)(2)

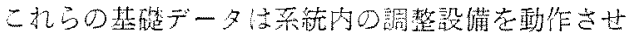
る際に，適切广操作量应決定する重要な尺度であるた

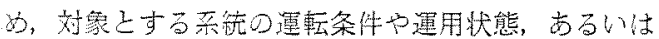
柔統の䜠特性が正しく反踖されていることが必要てお る。

第 1 表化示すよう代，こ机らの基礎ブータはすずて
䒺統内のある調整設喵を操作（あるいは，定数が变化） したをきの系統内の從属量の変化程度表表すす係数す なわ占感度に他ならない。した执って，感陵解析の立 場から見れば全く統一的に計算できる。本諭文はこの 点に注目し, 霓力系統の感度解析加ら得られる感度行 列 ${ }^{(7)(8)}$ に基づき，理々の基嘫デー夕在計算する方法化 ついて逨べる毛のである。

本諭文で提唱する感度行列に基つくく連用のための基 整データの決定法は，電力潮流方程式を古る遇用状態 を中心代拯動させ，えの結果得られるヤコビアン行列 基にして作られる感蜜行列它用いるものて，次に示 军上う持特徽を持っている。

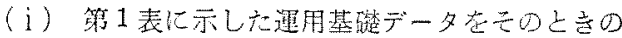
運用状態に対する感度行列汇基づき統一的に部算でき る。

（ii）系統の幾何学的構成のみならず系統の潮流快 態（重負荷時や軽負菏時の潮流状抬の相違）や速枟条 件（AVR，AQR 浬転など）に合致したデー夕が得ら

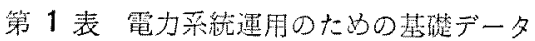

Table 1. Snsitivity constants for power system operation.

\begin{tabular}{|c|c|c|c|}
\hline 使用目的 & 運用におりる基譛データ & 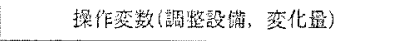 & 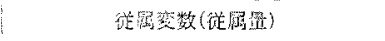 \\
\hline 荤用部画 & 安定璂対策計算のたわの安定度向上指数 & 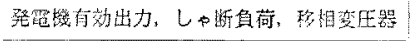 & 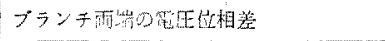 \\
\hline 平裳時涟用 & 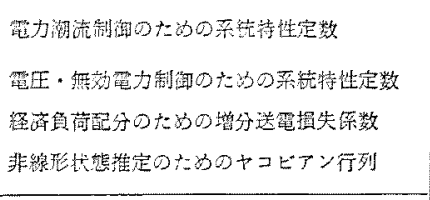 & 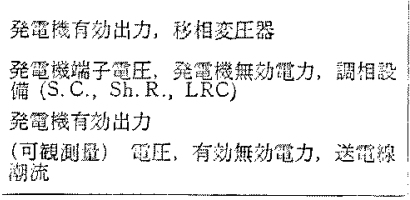 & 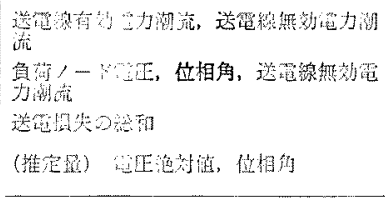 \\
\hline 雪故封韲用 & 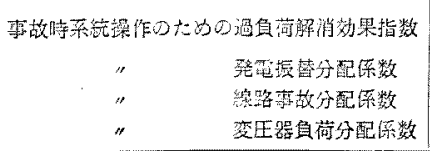 & 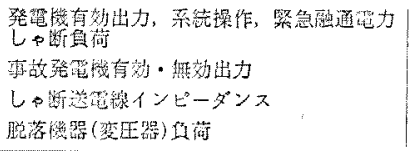 & 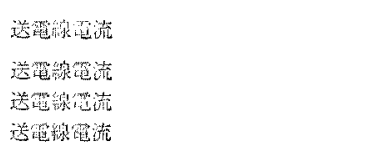 \\
\hline
\end{tabular}

Unified Approach to Determination of Sensitivity Constants for System Analysis and Control. By R. YOKOYAMA, Member (Depertment of Electrical Engineering. Waseda University)

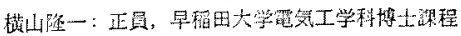


机る。

（iii）事故時における電力需給の不平衡分の配分力 法に忘じた感度行列を求的ることができ，また，発電 機の容最や調定率などの発電瀻特性あるいは電生，周 波数に対方分目荷特性在取り扱いやすい。

(iv) 精度の点加らは潮流計算によって得られる係 数之同等のデータが得ら机，計算封間の点からは交流 法による潮流計算の 1 回ふえ九たらずでよい。また，計 算プログラムは位来の Newton-Raphson 法の潮流計 算の6の亡共通点が多く部分的修正でよい。

ここでは，雷力潮流方程式に関する感度行列の諳 法について述へ，次に本手法をモデル系統に適用し， 絬果の妥当性を示す。

\section{2. 電力系統における感度行列}

系統軍用の基礎データを求必要となる電力 潮流方程式に関する感度行列，及び線路電力湖流に関 する感度行列の算出法について述心る。

$\langle 2 \cdot 1\rangle$ 電力潮流方程式之变数の分類 $N$ 佪の， 一ドをもつ一般の電力系統の電力潮流は, 次の $N$ 元 の複素数連立方程式で表わさ机る。

$$
\begin{array}{r}
P_{k}+j Q_{k}=C_{k}+j D_{k}+\dot{E}_{k} \sum_{\alpha}^{N}\left(\dot{Y}_{k \alpha} \dot{E}_{\alpha c}\right)^{*} \\
(k=1,2, \cdots \cdots, N) \ldots \ldots \ldots \ldots \ldots \ldots \ldots \ldots
\end{array}
$$

(1) 式を実部と虚部（有効電力分之無効電力分）に 分ける之 $2 N$ 個の方程式 $g_{2 k-1}=0, g_{2 k}=0(k=1,2, \cdots$, N) 肪得られる。すなわち，

$$
\begin{aligned}
g_{2 k-1}= & C_{k}-P_{k}+E_{k} \sum_{\alpha} E_{\alpha}\left\{G_{k \alpha} \cos \left(\theta_{k}-\theta_{\alpha}\right)\right. \\
& \left.+B_{k \alpha} \sin \left(\theta_{k}-\theta_{\alpha}\right)\right\} \ldots \ldots \ldots \ldots \ldots(2) \\
g_{2 k}= & D_{k}-Q_{k}+E_{k} \sum_{\alpha}\left\{G_{k \alpha} \sin \left(\theta_{k}-\theta_{\alpha}\right)\right. \\
& \left.-B_{k \alpha} \cos \left(\theta_{k}-\theta_{\alpha}\right)\right\} \ldots \ldots \ldots \ldots \ldots \ldots(3)
\end{aligned}
$$

て表豆㣗る。ここで，

$P_{k}, Q_{k}:$ ノドkに打ける発電有効・無効電

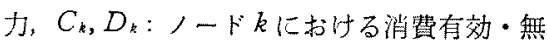
効䉓力, $E_{k}: ノ$ ノトkの電圧ベクトル $\left(=E_{k}\right.$

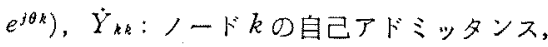
$\dot{Y}_{k \alpha}: ノ ー ト ゙ k \sim \alpha$ 間の相互アドミッタンス, $G_{k \alpha}, B_{k \alpha}:$ コンダクタンス, サセプタンス, $\alpha: ノ-ト k$ と之の隣接ノード，*：共役值， (2)，(3) 式は各ノードに书ける，発電及び 消費有効・䑤効電力, 電压, 位相角, コンダ クタンス，サセプタンスを变数とする $2 N$ 元 の実数連立方程式

こ机らの変数を感度解析の立場から便宜上, 次の 2 種頪に分類して考える。
（1）徒属変数ベクトル $X(2 N$ 次元列ベクトル) 通常の電力潮流計算における末知量の中で，母線の 有する未知量である。すなわち，母線の運用条件から

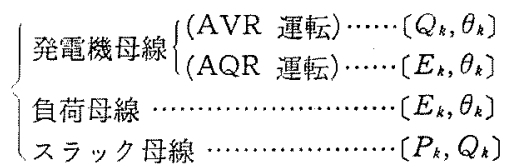

の上うに二つずつ定まる。(2)，(3)式に含ま机る各 母線汇関方分变数は $\left(P_{k}, Q_{k}, E_{k}, \theta_{k}\right)$ であり, 通常こ の四つの電気量のうち二つが指定量であるので，残り の二つが未知量上なる。したがって(2)，(3)式に含 まれる従属变数の総数は $2 N$ である。乙れは電力潮 流が一義的に定まる条件になる。

(2) 操作変数ベクトル $U(M$ 次元列ベクトル) 系統軍用に㧍ける調整設備の操作量住対応するもの であり，調整設備の種類に㐫じて，(2)，(3)式中の いず机を操作变数に選ふかかが決まる。操作变数として

（a）電力潮流計算に扔ける母線での指定量（既知 量）母線の種類により次の量が既知量である。

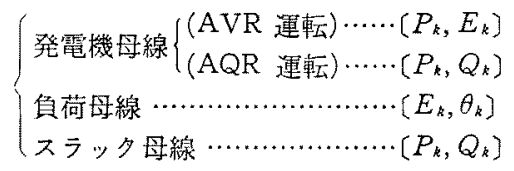

(b) 電圧・無効電力制御に打ける調相 設借蓝列キャパシタ(S.C.) リアクター(Sh.R.) $\left[D_{k}\right]$

(c) 各理変圧器〔(2)，(3)式には陽には含まれな (1)

負荷時電圧調整器タップ……[n]

移相変圧器 ………..... $\left[n e^{j \theta}\right]$

（d）負荷母線に抄ける目荷しゃ断…[C $\left.C_{k}+j Q_{k}\right]$

(e) 発電機脱落あるいは発電機のオフ

（f）線路のしゃ断事故(第 $l$ 線路) $\cdots\left[R_{j}+j X_{j}\right]$

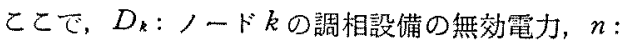
$L R C$ のタップ值, $n e^{j \theta}$ : 移相变圧器のタップ值(複素 量)， $R_{l}+j X_{l}$ : 線路lのインピーダンスである。操 作変数としては上述のように $C_{k}+j D_{k}$ あるいは $P_{k}$

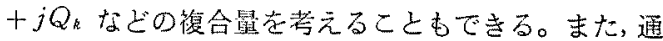
常の连用では不変な量である量たとえば送電線路及び 機器の定数も事故あるいは系統操作といった定数が变 化する場合には，操作变数々考えられるので，以下の 議論では操作変数の分類に含め一括して取り扱う。

$\langle 2 \cdot 2\rangle$ 電力潮流方程式に関する感度行列 前節 の分類によって定義された徉属及び操作変数を用いる と, (2), (3)両式は簡単江, 


$$
G\{X, U, \phi(X), \Psi(U)\}=0
$$

なるべクトル方程式で表わされる。ここで $G$ は $g_{2 k-1}$ 及び $g_{2 k}(k=1,2, \cdots \cdots, N)$ をその要素とする列べクト ルである。すなわち，次のように表わされる。

$$
G=\operatorname{col}\left(g_{1}, g_{2}, \cdots \cdots, g_{2 k-1}, g_{2 k}, \cdots, g_{2 N-1}, g_{2 N}\right)
$$

また，従属及で操作变数べクトル $X, U$ は

$$
\begin{aligned}
& X=\operatorname{col}\left(x_{1}, x_{2}, \cdots \cdots, x_{2 N-1}, x_{2 N}\right) \\
& U=\operatorname{col}\left(u_{1}, u_{2}, \cdots \cdots, u_{M-1}, u_{M}\right)
\end{aligned}
$$

なる列べクトルである。

ここで, $\phi(X)$ : 従属変数 Xにより定まる関

数， $\Psi(U):$ 操作変数 $U$ に上り定まる関数 とする。この二つの関数は (2), (3) 式の陽に含まれ ないが, 発電機有効出力操作仁伴う需給の不平衡の影 響古るいは発電機や目荷の特性を一般的に表現するた めに潮流方程式に導入したものである。 ${ }^{(9)(10)}$

さて，(4)式で表わさ机る電力系硫がある運転条件 $\left(X_{0}, U_{0}\right)$ で璭転されていたとき, 系統内のある調整設 備を操作して, 操作窝数のベクトルが $U_{0}$ からら $U_{0}+$ $\Delta U$ に変化したとする。このとき，電力潮流方程式を 満足するように, 從属变数べタトル $X$ が $X_{0}$ 加ら $X^{0}$ $+\Delta X$ に変化したとすると，次の関係が成立する。

$$
G\left\{X_{0}+\Delta X, U_{0}+\Delta U, \phi\left(X_{0}+\Delta X\right),\right.
$$$$
\left.\Psi\left(U_{0}+\Delta U\right)\right\}=0
$$

ここで, $\Delta U$ を铛少量とすると，(5)式を初期状態 $\left(X_{0}, U_{0}\right)$ を中心 Taylor 展開し，そして， $\Delta X$ 及び $\Delta U$ に関する二次以上の微少量を無視すると,

$G_{X} \cdot \Delta X+G_{U} \cdot \Delta U+(\partial G / \partial \phi \cdot \partial \phi / \partial X) \cdot \Delta X$

$$
+(\partial G / \partial \Psi \cdot \partial \Psi / \partial U) \cdot \Delta U=0 .
$$

ここで, $G_{X}$ : 関数べクトル $G$ の従属变数べ クトルXに関するヤコビアン行列 $(2 N$ 次元 正方行列)

$$
G_{X} \equiv \partial\left(g_{1}, g_{2}, \cdots \cdots, g_{2 N}\right) / \partial\left(x_{1}, x_{2}, \cdots \cdots, x_{2 N}\right)
$$

また， $G_{U}$ は関数べクトル $G$ の操作变数べクトル $U$ に関するヤコビアン行列 $(2 N \times M$ 次元行列 $)$

$$
G_{U} \equiv \partial\left(g_{1}, g_{2}, \cdots \cdots, g_{2 N}\right) / \partial\left(u_{1}, u_{2}, \cdots \cdots, u_{M}\right)
$$

である。(7),(8)式のヤコビアン行列は通常の交流 法に上る潮流計算 (Newton Raphson 法)で用いられ るヤコビアン行列上全く同じ方法によって計算され る。ヤコビアン行列の要楞は各母線の運転条件により 定まり，また母線間の接続状態（幾何学的構成）によ つて影篦を受ける。

一方，(6)式の第 3 項及び第 4 項は系統の諸特性を 潮流方程式に含めるために追加した関数 $\phi(X), \Psi$
(U) によるヤコビアン行列 $G_{X}, G_{U}$ に対する修正項 である。この関数は变数 $X, U$ に関して一階微分可能 であればよく，この関数によって種々の基碄データを 求める際の系統特性を一括して取り扱える。てれにつ いては第3章に求いて詳しく説明する。

ここで，(6)式から次の関係が得られる。

$$
\begin{aligned}
\Delta X & =S \cdot \Delta U \quad \ldots \ldots \ldots \ldots \ldots \ldots \ldots . . \\
S \equiv & -\left[G_{X}+(\partial G / \partial \phi \cdot \partial \phi / \partial X)\right]^{-1} \\
& \times\left[G_{U}+(\partial G / \partial \Psi \cdot \partial \Psi / \partial U)\right]
\end{aligned}
$$

であり, 〔 正は逆行列を示す。

(10)式で与えられる係数行列 $(2 N \times M$ 次 $)$ は, 電 力潮流の操作変数べクトルUに関する感度行列之呼 ばれるものであり，この行列の要素は直接第 1 表の基 碟データに対応するものである。たとえば，Uべク トルのある要素れ，並列キャパシタの投入量とし $X$ ベクトルのある要素 $x_{i}$ を従属量であるノード電生 之考えれば，乙の両者の比 $\Delta x_{i} / \Delta u_{j}$ は感度行列 $S$ の 要素 $S_{i}$ で与えられている。これは電圧・無効電力制 御に用いら杞る系統特性定数化他ならない。このよう に変数べクトル $U$ 及び $X$ としてどの量を選定するか によって第 1 表の基整データの種類が決ってくるわけ で, 計算は感度方程式(10)式に上って統一的に取り报 うことができる。

\section{〈2.3〉 線路電力潮流及ひ電流に関する感度}

第 1 表の従属变数の中には, 送電楾路を流れる電力 潮流あるいは線路電流が含まれている。これらの帡属 量に対する感度は次のようにして得られる。まず，線 路彷属量は両端ノードの従属及び制御变数の関数 $F$ $(X, U)$ で表わされる。 $\langle 2 \cdot 2\rangle$ 節之同様使調節設備に よって状態が $\left(X_{0}+\Delta X, U_{0}+\Delta U\right)$ に変化したとする と線路潮流及び電流も $\Delta F$ だけ変化する。すなわ方,

$$
\begin{gathered}
\Delta F\left(X_{0}, U_{0}\right)=F\left(X_{0}+\Delta X, U_{0}+\Delta U\right) \\
\quad-F\left(X_{0}, U_{0}\right)
\end{gathered}
$$

(11)式を(6)式と同様任 Taylor 展開する之

$$
\begin{aligned}
& \Delta F\left(X_{0}, U_{0}\right)=F_{X}\left(X_{0}, U_{0}\right) \cdot \Delta X \\
& \quad+F_{U}\left(X_{0}, U_{0}\right) \cdot \Delta U \ldots \ldots \ldots \ldots
\end{aligned}
$$

(12)式加ら次の関係を得る。

$$
\begin{aligned}
S_{F} & \equiv\left\{\Delta F_{i}\left(X_{0}, U_{0}\right) / \Delta U\right\} \\
& =F_{X}\left(X_{0}, U_{0}\right) \cdot(\Delta X / \Delta U)+F_{U}\left(X_{0}, U_{0}\right)
\end{aligned}
$$

ここで, $S_{F}$ : 操作变数 $U$ 亿関する線路潮流 の感度, $F_{X}, F_{U}$ : 楾路潮流 $F$ の変数 $X$ 及 び $U$ に関する微分項， $(\Delta X / \Delta U):(10)$ 式 で与えられる感度行列

ノード $k$ からノード $m$ に向かう線路潮流及び霓流 
は雨端ノード $k, m$ の電代及び位相角の関数で与えら れる。したがって，X三( $\left.E_{k}, E_{m}, \theta_{k}, \theta_{m}\right)$ となり，乙れ らの要素で関数 $F$ を偏徽分すること加ら $F_{X}$ 支るい は $F_{U}$ は容易化得られる。 ${ }^{(14)}$ また，ある操作変数を操 作したときのノード従属量 $E_{k}, E_{m}, \theta_{k}, \theta_{m}$ の変化分 $(\Delta X / \Delta U)$ はすでに感度行列 $S$ 要素として求ってい るので，(13)式は直ちに計算することができる。(13) 式方系統内のある調整設徣を操作したときの線路潮流 あるいは線路電流の変化を表わ吉感度を与えている。

\section{3. 系統運用のための基礎データの決定法}

ここでは，(10)及び(13)式で与えられる感度行列老 用いて第 1 表に示した個々の基嘫データの決定する方 法について述へる。また，之の際の有効電力操作化伴 う需給不平衡の考え方や系統特性の取り扱いについて 述へる。

〈3.1〉 有効電力の操作に伴う需給不平衡 発電 僟端子電王や調相設備の操作の効果程度を表扣す系統 特性定数化対し，事故時系統操作江用いられる過負菏 解消効果係数古るいは采統安全化対策計算に用いら机 る安定度向上指数の場合注，調整設備之して発電璣有 効出力を操作するのて，操作化伴う需給の不平衡仁上 る影響任対する考慮が必要となる。この需給の不平衡 による影響は系統全域の周波数の痛異という全体的性 格を有して扔り，おの扔のの基礎データを算出する際 に無視することのできないものである。本論文では， 有効電力操作に伴う需給の不平衡を次のように取り报 う。

いま, 系統内の第 $l$ 発電機の有效出力を $\Delta P_{l}$ (p.u.) だけ增加させたとき（または $\Delta P_{l}$ の需給不平衡が発 生した上き)，過渡的変動がおさまった後の定常的周 波数偏差 $\Delta f$ は(14)式で表方される。

$$
\begin{aligned}
& \Delta f=\Delta P_{l} /\left[K_{L}+\sum_{\substack{i \\
i \neq l}} P_{R i} /\left(R_{i} f_{0}\right)\right] \\
& =\Delta P_{l} /\left(K_{L}+K_{G}\right)
\end{aligned}
$$

ただし， $K_{L}, K_{G}$ : 負荷・発電機特性定数 $(\mathrm{p}$.

u. $/ \mathrm{Hz}) ， f_{0}$ : 定格周波数 $(\mathrm{Hz}), P_{R i}, R_{i}$ : 第

$i$ 発電機定格容最。調定率 (p. u.)

周波数偏差 $\Delta f$ に対して調速機の始動によって， 他の発電機の有効出力は(15)式で表わさ机る $\Delta P_{k l}$ (減 少分）だけ变化する。

$$
\left.\Delta P_{k l}=-P_{R k} / R_{k} f_{0}\right) \Delta f
$$

ただし， $\Delta P_{k l}$ : 第 $l$ による第 $k$ 発䉓機の有効

出力变化量

(14)，(15)両式加ら(16)，(17)式汃得られる。

$$
\Delta P_{k l}=-\left\langle P_{R k} / R_{k} f_{0}\right) / K_{L}
$$

$$
\begin{aligned}
& \left.\left.+\sum_{\substack{i \\
i \neq l}} P_{R i} / R_{i} f_{0}\right)\right\} \Delta P_{l} \\
= & -\left\{K_{k l}\right\} \Delta P_{l}-\ldots \ldots \ldots . . .
\end{aligned}
$$

$K_{k 2}$ は符 $l$ 発電機有勃出力をある量だけ操作したと きの第 $l$ 発電機出力の变化分を示主係数であり, “発 電振替係数”之咋ぶとにする。(17)式を用いれば系 統内に発生した需給の不平衡が各発電機の特性あるい は負荷特性に従って分担され，新たな平衡潮流状態に 移行する状沉を容易に表現できる。(10)(13)

〈3.2〉発電振替分配係数 発電振替分配係数 (Generation-shift distribution factor) は, 系緒内の発 電機脱落事故（事故発電機 1p.u.）おたりの送電線路 への影響を表わす効果係数である。 ${ }^{(6)(9)}$ 発電機事故に よってその発電機の発生していた出力 $\left(P_{t}+j Q_{l}\right)$ 分 の需給不平衡が系統内に生じる。この影響により(14) 式の周波数偏哄が起こり, 系統内の他の発電機や負荷 がその特性に応じて不平衡分を分担した新たな状態に 移行する。この変化が各送霓線路の潮流や電流に対し てどの程度の影響を及ばすか示すのが発電振替分配 保数であり，運用計画に拈ける仮想事故に対する信頼 度チェックに用いら机る。 ${ }^{(1)}$

発電振替分配係数屯感度方程式 (10)，(13) 式によ。 て計算されるが，有効電力の变化化伴う需給の不平衡

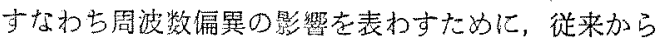
用いら机ている電力潮流方程式を若干修正する。第 $l$ ノードの発電機事故 $\left(\Delta P_{1}+j \Delta Q_{1}\right.$ の脱落) とそれに 上る周波数偏異によって影響を受りるのは，需給不平 衡の原因であるlノード，調速機芯動を行なう発電㙨 起有する第 $k$ ノ一ドと負荷を有する第 $m$ 八ードである から，方れぞれのノ一ド詨する電力潮流方程式の修 正項は第 2 表(a)上なる。だ゙し， $\Delta f$ は(14)式， $K_{k 2}$ は(17)式で与えられる。また， $P_{\text {set }}, Q_{\text {set }}, C_{\text {set }}, D_{\text {set }}$ は 有効無効電力の設定随, $n^{C}, n^{D}$ 注有效無效負荷の周波 数特性指数である。目荷特性は定常時負荷のべき級数 で丧現されるとした。 ${ }^{(3)}$ 第 $l, k, m$ 以外のノード怙通常 の(2)，(3)式在用いれば上い。

発電振替分配保数は第2 表( a) の鲀正を行なった潮 流方程式走用いて，(10)，(13) 両感度方程式によって

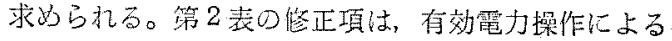
影㗽を表わすものであるから，操作变数（この場合は 有効出力）に上って定きる関数 $\Psi(U)$ で表わすこと ができる。ここで，(10)式を計算する場合，ヤコビア

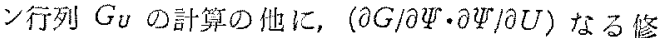
正項老加える必要がある。操作変数は $\left(P_{t}+j Q_{t}\right)$ で あるから、ヤコビアン行列の要素は(a)の各潮流方程

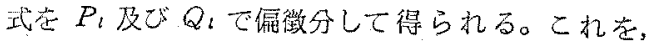


第 2 表 電力潮流方程式とヤコビアン 行列の修正

Table 2. Modification of power flow equation and jacobian matrix.

\begin{tabular}{|c|c|c|c|}
\hline & $1-r$ & 電力潮流方程式心仵正瑱 & ヤコビナン行列上鋚正項 \\
\hline \multirow{3}{*}{ (a) } & $l$ & 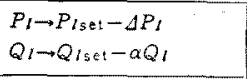 & $\begin{array}{l}\partial g_{2 /-1} / \partial U_{J}=1 \\
\partial g_{2 l} / \partial U_{l}=q l\end{array}$ \\
\hline & $k$ & $\begin{array}{l}P_{k} \rightarrow P_{k \text { set }}+K_{k} / \Delta P l \\
Q_{k} \rightarrow Q_{k \text { set }}\end{array}$ & $\begin{array}{l}\partial g_{k k-1} / \partial U_{l}=-K_{k l} \\
\partial g_{2 k} / \partial U_{l}=0\end{array}$ \\
\hline & $m$ & 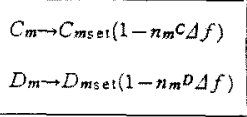 & 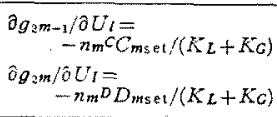 \\
\hline \multirow{2}{*}{ (b) } & $l$ & $\begin{array}{l}P t \rightarrow P l_{\text {set }}+\Delta P t \\
Q t \rightarrow Q t_{\text {set }}\end{array}$ & $\begin{array}{l}\partial g_{z} /-1 / \partial P_{l}=-1 \\
\partial g_{z} / / \partial P_{l}=0\end{array}$ \\
\hline & $k$ & 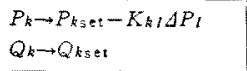 & $\begin{array}{l}\partial g_{2 k-1} / \partial P_{l}=K_{k l} \\
\partial g_{2 k} / \partial P_{l}=0\end{array}$ \\
\hline
\end{tabular}

(a)の右列化示京。ただし，q! は事故発電機 $l$ 加発

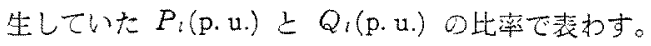
一方，位属変数ベクトル $\mathrm{X}$ 亿関する関数ベクトル $G$ のヤコビアン行列 $G_{X}$ は通常の Newton Raphson 法 潮流計算の堨合と全く同様汇計算す机ばよい。( ${ }^{(8)(9)}$

上述のヤコビアン行列を用いて(10)式加ら感度行列 を求め, 次に(13)式により線路電流に関する感度を計 算すれば，これが求める発電振替分配俰数である。

\section{$\langle 3 \cdot 3\rangle$ 過負荷解消効果指数 過負荷解消効果指}

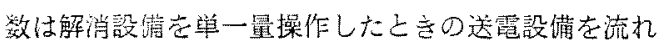
る電流の变化を表わす指数ですり，過負荷軽減のため の発電力の再配分のみならず, 柔統操作 (系統切り替 え，ブス切り前えなど〉の決定に用いら礼る。(1)(2) 過 負荷解消操作は発電㙨事故の場合上は翼なり, 発電力 の振り替えを主体とするものである。したがって，発 電機出力の操作量の総和が雾に保亡れる上うに, すな

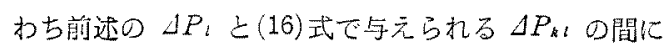

$$
\Delta P_{l} \simeq \sum_{k} \Delta P_{k l}
$$

の関倸が成立するように発電機間で有效出力が增減さ

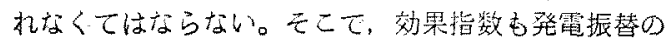
方策が異な机は值が買なることは明らかである。本力 法では感度行列を求的万際に, 需給不平衡分の配分方 法を発電振替倸数によって一般的に取り报うことによ り，より寒情に即した解消指数を求めることができ る。まず，(18)式が成立する振替方法として通常行な わ机るもは，発電機 $l$ の操作に上る需給の不平衡分 を他の発電機の定格容量上調定率に從って配分する方 法である。この場台, 発電振替係数は,

$$
K_{k l}=\left\{\left(P_{R k} / R_{k} f_{0}\right) /\left(\sum_{\substack{i \\ i \neq l}} P_{R i} / R_{i} f_{0}\right)\right\}
$$

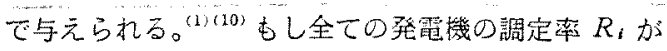

等しければ，(19)式は(20)式となる。

$$
K_{k l}=P_{R k} / \sum_{\substack{i \\ i \neq l}} P_{R i}
$$

この場合には, 不平衡分は他の発電僟の定格容量に 比例配分さ机る。また，特定の発電機 $k$ が不平衡分索 すへてて調整するように運用する埸合も伱数 $K_{k l}=1$ 上 与えればよい。このように係数 $K_{* 1}$ を用いることに 上って発電機出力の振替の方策を容易に取り扱うこと ができる。過負荷解消効果指数を求好る計算は $\langle 3 \cdot 2\rangle$ 節と同じであるが, 操作变数は発電機有効出力 $\left(P_{l}\right)$ であることと，周波数噼買 $\Delta f=0$ であることから使 用する電力潮流方程式は $g_{2 l-1}$ 上 $g_{2 k-1}$ のみ加修正項 を含む。乙机を第 2 表(b)に示す。一方，ヤコビアン 行列 $G_{U}$ は(b)の各式を $P_{l}$ て偏微分することにより (b)の右側に示すようになる。〈3.2〉節と同じく(13) 式加ら電流の感度を求孙ば過負荷解消効果指数が得 られる。(14)

\section{〈3.4〉安定度向上指数及び增分送電損失係数}

安定度向上指数は調整設请在単位量操作したときの ある楾路両端間の電圧位相差の変化の程度を表わす指 数で, 運用計画のための安定度解析あるいは系統安定 化対策に沶いて重要な効果係数である。(1)(9)一方, 增 分送電損失係数はある発電機有効出力を操作したとき の系統送電損失の变化程度を表和す効果指数で，定常

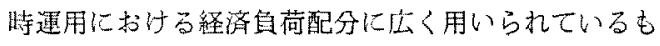
のである。この二つの効果係数屯第 1 表の他の係数之 同じく感度行列から算出されるが，これらは他の効果 係数を求的る際に副次的に得られる利点がある。

(1) 安定度向上指数系統内の古る調整設備

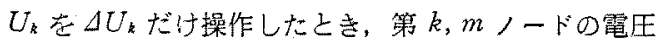
位相角 $\theta_{k}, \theta_{m}$ が拉のおの $\theta_{k^{\prime}}, \theta_{m^{\prime}}$ 儿变化したとすれ ば，安定度向上指数は，操作 $\Delta U_{k}$ によって生ずる電 正位相差 $\left(\theta_{k} \sim \theta_{m}\right)$ 变化程度を示す係数であるから ${ }^{(1)}$ 次式の上うになる。

$$
\begin{aligned}
S_{k \sim m^{\theta}} & \left.=\left(\theta_{k}{ }^{\prime}-\theta_{m}{ }^{\prime}\right)-\left(\theta_{k}-\theta_{m}\right)\right\} / \Delta U_{k} \ldots(21) \\
& =\left(\theta_{k}{ }^{\prime}-\theta_{k}\right) / \Delta U_{k}-\left(\theta_{m^{\prime}}-\theta_{m}\right) / \Delta U_{k}
\end{aligned}
$$

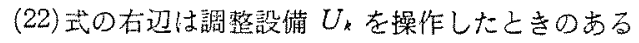
ノード電压位相角の变化を表わす感度に他ならない。 これは㙅作変数 $U_{k}$ に対する感度行列の一要素として すでに(10)式で求まっている。したがって, 第 $i, j$ ， 一ドの電生位相角の感度 $S_{k}{ }^{8}, S_{m}{ }^{8}$ を用いて

$$
S_{k \sim m}{ }^{\theta}=\left(S_{k}{ }^{\theta}-S_{m}{ }^{\theta}\right)
$$

として, 安定度向上指数が与元られる。

（2）增分送電損失係数，第 $k \sim m$ /ード間の第 $j$ 線路について考元れば，線路挰失 $L_{j}$ はノードk 
ら $m$ への潮流とノード $m$ から $k$ への潮流の相造から 次式で与えら机る。

$$
L_{j}=F_{k m^{j}}(X, U)+F_{m k^{j}}(X, U)
$$

系統の全擅失 $P_{L}$ は全ての線路電流の総和で,

$$
L_{j}=\sum_{j=1}^{J}\left\{F_{k m^{j}}(X, U)+F_{m k^{j}}(X, U)\right\}
$$

ただし， $J:$ 送電線路の総数， $X:$ 徒属变数，

一般に, $X=\left(E_{k}, E_{m}, \theta_{k}, \theta_{m}\right) ， U:$ 操作変数

で与えられる。

增分送電損失保数は定義により次式で与えられる。

$$
\begin{aligned}
\partial P_{L} / \partial U_{k}= & \sum_{j=1}^{J}\left\{\partial F_{k m^{j}}(X, U) / \partial U_{k}\right. \\
& \left.+\partial F_{m k^{j}}(X, U) / \partial U_{k}\right\}
\end{aligned}
$$

(26)式中の右辺はある調整設備 $U$ kを操作したとき の線路 $j$ の潮流の感度の和である。この感度はすでに (13)式で与えられており，(26)式は直与江求まる。

\section{4. モデル系統に対する適用結果}

ここで述べた計算法を第1図のモデル系統に適用し た結果について説明する。第 3 表はモデル系統の邁用 条件及び負荷状態を示している。第 3 表中の基準状 態（Case 1) の負荷状態に $k=1.25 ， 1.5 ， 1.75 ， 2$ な る係数を乘して 5 種の負荷状態を想定した。表には Case 1 とCase 5(重負荷状態)のみを示してある。

(1) 調整設诵上して発電機有効出力 $\left(G_{2}, G_{3}, G_{4}\right.$, $\left.G_{10}, G_{1}\right)$ を選び，発電機の操作に対する線路電流及び 線路両踹の電王立相差の変化を表わす係数，すなわ 声, 過負荷解消效果指数及ご安定度向上指数老感度行 列に基づき求めた結果が第 4 表である。

これはCase 1 に対する結果であり，また第 3 章で 述べた需給不平衡の配分は各発電機の定格容量に比例 して振替える条件 $(20)$ 式を用いた。また，同表には実

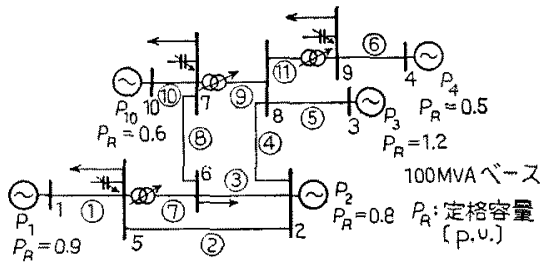

第 1 图モデル系統

\begin{tabular}{|c|c|c|c|c|c|}
\hline & NODE & $E(p$, u. $)$ & $\theta($ Deg. $)$ & $P(p, u)$. & $Q($ p.u.) \\
\hline \multirow{10}{*}{$\begin{array}{l}\text { Case } 1 \\
\text { (Base) }\end{array}$} & 1 & 1.110 & 0.000 & 0.866 & 0.422 \\
\hline & 2 & 1.035 & -8.947 & 0.600 & 1.249 \\
\hline & 3 & 1.020 & 1.072 & 1.100 & 0.268 \\
\hline & 4 & 0.050 & -7.216 & 0.250 & 0.350 \\
\hline & 5 & 0.982 & -10.492 & -0.900 & -0.358 \\
\hline & 6 & 0.962 & -11.551 & -0.420 & -0.350 \\
\hline & 7 & 0.963 & -11.053 & -0.450 & -0.199 \\
\hline & 8 & 0.973 & -9.317 & & -0.300 \\
\hline & 9 & 0.961 & -10.421 & -1.350 & -0.677 \\
\hline & 10 & 1.000 & -7.573 & 0.400 & 0.197 \\
\hline \multirow{10}{*}{$\begin{array}{l}\text { Case } 5 \\
(k=2.0)\end{array}$} & 1 & 1.110 & 0.000 & 2.094 & 1.219 \\
\hline & 2 & 1.035 & -29.436 & 1.200 & 3.356 \\
\hline & 3 & 1.020 & -7.660 & 2.200 & 1.009 \\
\hline & 4 & 1.050 & -26.050 & 0.500 & 0.775 \\
\hline & 5 & 0.831 & -30.532 & -1.800 & -0.716 \\
\hline & 6 & 0.860 & -35.166 & -0.840 & -0.700 \\
\hline & 7 & 0.875 & -34.382 & -0.900 & -0.398 \\
\hline & 8 & 0.886 & -30.426 & & 0.600 \\
\hline & 9 & 0.856 & -33.147 & -2.700 & -1.354 \\
\hline & 10 & 1.000 & -27.164 & 0.800 & 0.745 \\
\hline
\end{tabular}

Fig. I. Test system.

第 3 表 負荷犾態之運転条件

Table 3. Load and operational conditions.

際に有効電力を䟕分して潮流計算を実行するこよによ り求めた指数（真値）手併記してある。

（2）第 3 表の茞々の目荷状態住対する感度行列を 求め. それに基づき得引れた渦目荷解消效果指数 安

\begin{tabular}{|c|c|c|c|c|c|c|}
\hline 指 & \multicolumn{3}{|c|}{ 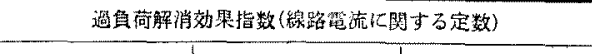 } & \multicolumn{3}{|c|}{ 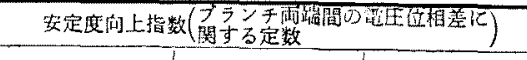 } \\
\hline プランチ & $G(2)$ & $G(3)$ & $G(4)$ & $G(2)$ & $G(3)$ & $G(4)$ \\
\hline $1-5$ & $-0.022(-0.022)$ & $0.032(0.035)$ & $-0.022(-0.023)$ & $-0.33(-0.37)$ & $0.56(0.54)$ & $-0.38(-0.39)$ \\
\hline $2-5$ & $0.037(0.035)$ & $-0.007(-0.036)$ & $0.009(0.007)$ & $1,18(1.17)$ & $-0.22(-0.26)$ & $0.30(0.29)$ \\
\hline $2-6$ & $0.092(0.092)$ & $0.017(0.017)$ & $0.003(0.003)$ & $2.35(2.35)$ & $0.25(0.25)$ & $0.20(0.19)$ \\
\hline $2-8$ & $0.056(0.060)$ & $0.005(0.055)$ & $-0.097(-0.096)$ & $3.63(3.65)$ & $-2.5)(-2.50)$ & $-1.55(-1.54)$ \\
\hline $3-8$ & $-0.613(-0.613)$ & $0.978(0.973)$ & $-0.516(-0.517)$ & $-6.12(-6.12)$ & $9.74(9.74)$ & $-5.12(-5.13)$ \\
\hline $4-9$ & $-0.080(-0.080)$ & $-0.089(-3.039)$ & $0.504(0.511)$ & $-2.09(-2.09)$ & $-3.94(-2,95)$ & $14.7(14.7)$ \\
\hline $5-6$ & $0.032(0.034)$ & $0.018(0.016)$ & $-0.006(-0.006)$ & $1.18(1.19)$ & $0.48(0.51)$ & $-0.10(-0.09)$ \\
\hline $7-6$ & $-0.261(-0.261)$ & $-0.044(-0.044)$ & $-0.013(-0.013)$ & $-1.05(-1.05)$ & $-0.17(-0.17)$ & $-0.06(-0.06)$ \\
\hline $8-7$ & $-0.033(-0.023)$ & $0.270(0.270)$ & $0.179(0.177)$ & $-0.23(-0.25)$ & $2.93(2.92)$ & $1.81(1.80)$ \\
\hline $8-9$ & $0.133(0.133)$ & $0.187(0.185)$ & $-0.932(-0.933)$ & $0.15(0.15)$ & $0.25(\quad 0.24)$ & $-1.16(-1.17)$ \\
\hline $7-10$ & $0.179(0.202)$ & $0.139(0.139)$ & $0.163(0.169)$ & $-2.14(-2.14)$ & $-3.01(-3.00)$ & $-1.78(-1.77)$ \\
\hline
\end{tabular}
定度向上指数の值上負荷状態との関連を示したのが第

第 4 表 猧負荷解消效果指数及び安定度向上指数

Table 4. Sensitivity constants for power system operation.

（）内は湖流訫算より求めた措数 


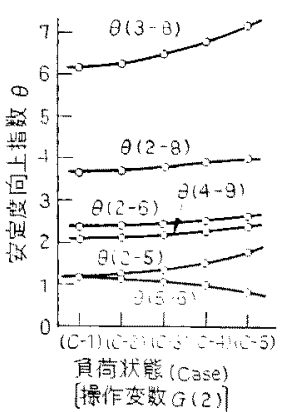

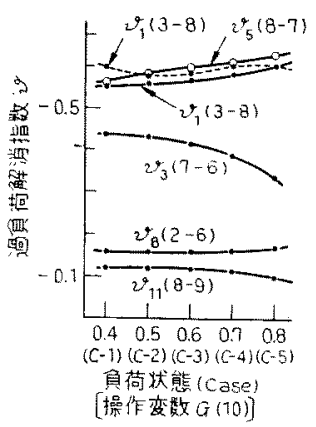

[操作变数 $Q(70)]$

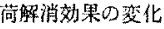

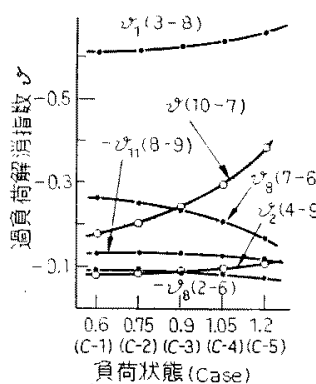

首荷状意(Case)

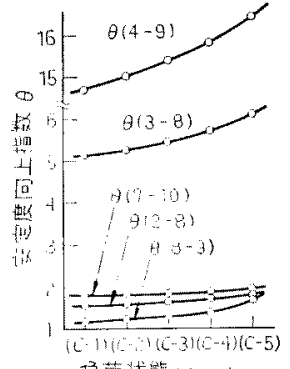

角荷犹繁( Cose) $[$ 魦作惁 $G(4)]$

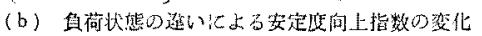

第 2 图 負荷状態の邀い络上る感度定数の変化

Fig. 2. Change in sensitivity constants by load conditions.

2 図である。また，五つの負荷状態における発笪㙨出 力操作関する增分送電損失係数毛(27)式を用いて副 次的に求まる。

（3）調整設䚛のうち, 調相設備の一つである並列 キャパシタ（S.C.) などを選び，この操作代対する系 統従属量の变化を示す保数, すなお電圧無効電力に 関卞る系統特性定数吉 Case 1 亿扔いて求め, こ机と 潮流計算によって求めた值を比較したのが第 3 図( a ) である。操作量の大きさと定数の変化を調べるために 潮流計算において $\Delta$ S. C $\mathrm{C}_{(9)}=0.03 \sim 0.12($ p. u.) にわ
たり有限量ずつ変化させて求め, それぞれの系統特性 定数を縦軸にプロットしてある。また，感度行列から 求めた定数は，基準状態(Base) の部分に示してあ る。第 3 図(b)は Case 1 Case 5 にわたる5 種の負 荷状態において感度行列加ら求好た系統特性定数の变 化を示したものである。

以上がモデル系統への適用結果の一部であるが，こ れらから以下の点が明らかとなった。

(i) 交流潮流計算加ら得ら机了係数之の比較（第 4 表）加ら，感度行列法の結果の妥当性が示された。
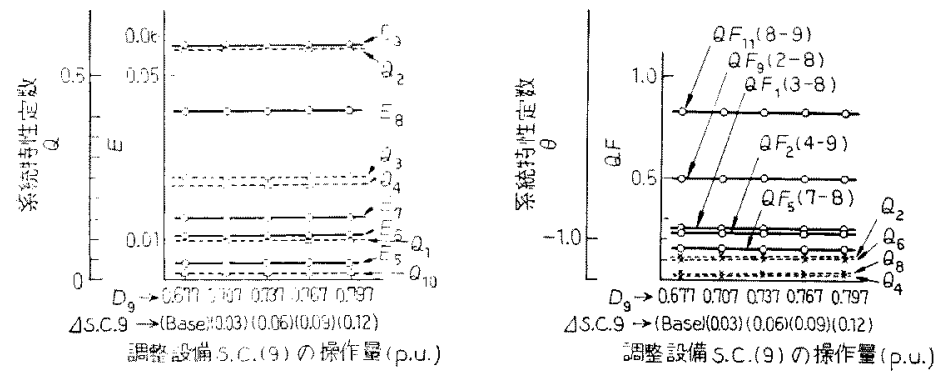

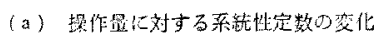

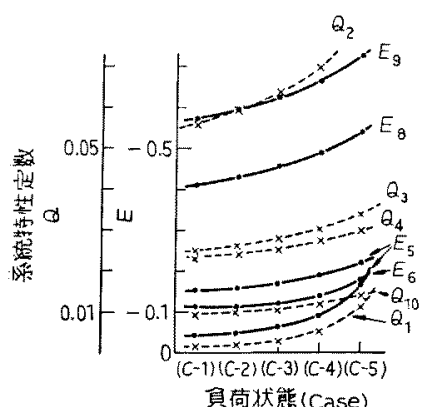

[搡作数 S.C.(9)]

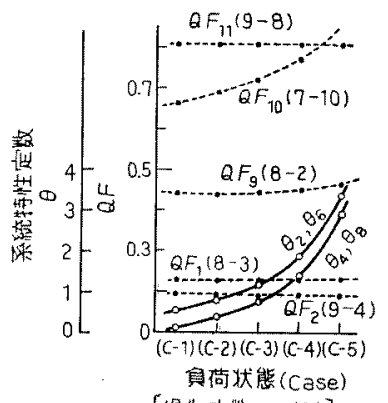

[擦作变数S.C.(9)]

(b) 負尚状態の進い上よる系統特性定数の变化

第3図操作量及び負荷状態の逵いによる系統特性定数の变化

Fig. 3. Change in sensitivity constants by control and load conditions.

(ii) 負荷状態によって係 数の值が大さく影響を受ける ととがわかる。第 2 図，第 3 园(b)]また，有效電力を操 作する場合には需給不平衡と その配分方法を十分考感する 必要がある。

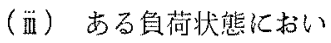
て精度良いデータを求めて打 けば，調整設備の操作量をか なり大幅に変化させても, 同 じ定数を用いることが可能て ある。[第3图(a)]

なお，このモデル乘統での 計算所矮時間は, UNIVAC 1108, FORTRAN (入出力6 含む）で第 1 表のす心゙ての基 礎デー夕在求めるのに，約 1 秒であった。

\section{5. 考 察}

本論文では電力乐統理用に 用いられている種々の基礎デ 
一タが，系統內のある調整設徣の操作に対する系統各 所の促属量の変化を表水す感度であることに注目し， 個々の基碳データ在感度行列に基づいて統一的に算出 する方法について述にた。第4图は本手法の計算つロ 一乙第1 表の基礎データ類がいずれの操作变数上徥属 变数上の間の感度関係を表わすもの加を概念的に示し たものでる。

本論文で提唱した方法は，徉来考虑が不十分であ。 た点，た上えば有効電力の操作に伴なう需給不平衡の 影复，三の配分方法，発電㙨や真荷の特性などを取り 扱いやすく，一方，重負荷柽目荷といった潮流状態化 合效した基礎データが得ら机る利点がある。感度行列 在求める祭に必要であるヤコビアン行列の計算プログ ラムは，徒来の Newton Raphson 法潮流計算のそれ と共通点加多く部分的修正でよい。(10) 式中のヤコビ アン行列 $G_{X}$ は，系統構成上負荷状態によって決まる 屯のであり，第1表の個々の基整データ在算出する場 合に共通して使用できる。こてで，斿る運用状態に刘 寸る $[G x] の$ 逆行列老用意して打けば，必要となる基 礎データに忘じた $G_{U}$ を計算して個々のデータを求め ることができ、データ・バンクの共有が可能である。

一方，本手法の記镱容量之計算所要時間は，ヤコビ アン行列 $G_{X}$ (2N 正方行列) の大きさ之その逆行列の 演算洔間に依存している。しかし，ヤコビアン行列は

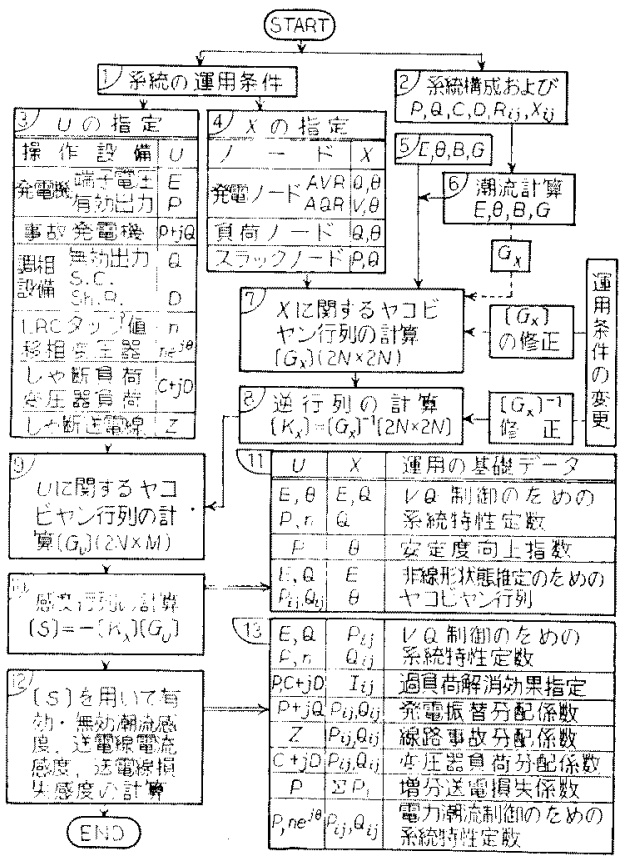

第 4 困 運用基峂データの計算フロー

Fig. 4. Flow chart of sensitivity method.
極好て Sparse な行列であることから，潮流計算で用 いられる Sparse 行列処理，三角因数化法 ${ }^{(12)}$ 利用卞 ることによって計算の效率化が計れる。また，系統の 一部のみの基怔データがあればよい場合には，系統の 一部の感度のみを計算する分割法 ${ }^{(9)}$ も開発されてい る。感度行列は系統内の操作量之従属量の関係を線形 近似によって表和すものであるが，調整設储の操作量

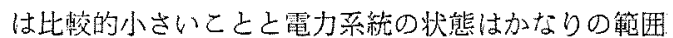
まで線形的伅変化することから，ここでの近似は妥当 である。また，操作が大幅な場合にも，感度行列が与 无る径属量の变化の方向上大小関係は正しい目安之な るので，緊急時の制御に対しても利用できよう。

ここに述べた方法も，実系統を模擬してデータを算 出するものであるから，あくまで真值の近似解を得る に立ざない。したがって，その精度も系統模擬の忠害 度に依存している上いえる。气机が適切であればきわ

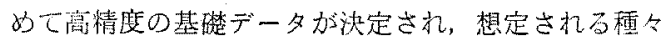
の運転条件や将来系統についての計算屯可能である。 しかし，実際には負荷特性なよ゙の系統特性む十分はあ くさ机ておらず，配電系統といった下位系統を省略す

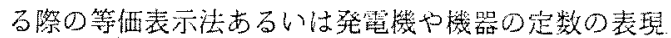
法なども不十分であり，これらの䛊差によって基醕デ 一タが実情に即さない恐机毛多い。今㖟この方面への 研究が大いに望まれる上ころである。

最㣪にこの論文の作娍にあたって名くの检䞑をいた だいた早槄田大学田村康男教授，同成田詖之助助教 授，ならびに同電力研究室院生諸君に泚く謝意を表す る次第である。

（昭和 47 年 11 月 2 日受付，同 48 年 3 月 26 日再受付）

\section{文献}

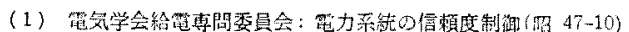

(2) 鍮木·尾出: 技術報告 No66032（昭 41-8)

（3）小宮，做：技術款告 No.70045 (昭 45-10)

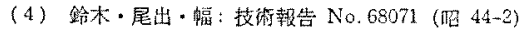

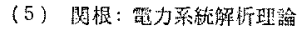

(6) W.S. Ku \& P. Van Olinda: PICA 1969 C. Re. p. 201 (1969)

(7) J. Peshon, et al. PICA 1967 C. Re. p. 209 (1967)

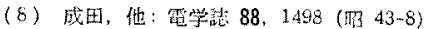

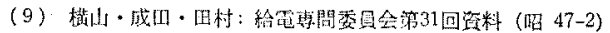

(10) 㮖山・成四：昭47電力学全速合尖全 No.677

(11) J.R. Richard: IEEE Trans. Power Apparatus Syst. PAS90, $5(1971-5)$

(12) R. Baumann: IEEE Trans. Power Apparatus Syst. PAS8511, p. 1164 (1960்-11)

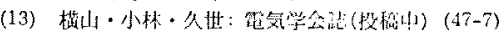

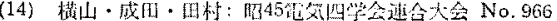

